\title{
Pengaruh Pola Anyaman terhadap Perilaku Lentur Textile Reinforced Concrete (TRC) dengan Perkuatan Serat Rami
}

\author{
(The Effect of Woven Patterns on Flexural Behaviour of Textile Reinforced \\ Concrete (TRC) with Ramie Fiber Reinforcement)
}

\author{
Arief Budiman $^{1 *}$, Erizal $^{1}$ \\ ${ }^{1}$ Departemen Teknik Sipil dan Lingkungan, Fakultas Teknologi Pertanian, Institut Pertanian Bogor. \\ Jl. Raya Dramaga, Kampus IPB Dramaga, PO BOX 220, Bogor, Jawa Barat Indonesia \\ * Penulis korespondensi: arifbudiman184@gmail.com
}

\begin{abstract}
The demand of concrete has increased in Indonesia. A reinforced concrete innovations currently being developed is Textile Reinforced Concrete (TRC). Ramie fiber has great potential to be used as a construction material because it has advantages over other natural fibers, such as tensile strength properties. The woven pattern has an effect on the strength of the TRC composite material. The research was carried out through several stages, that are testing of TRC materials, mix design, weaving and coating ramie fiber, manufacture and curing of test objects, and mortar compressive strength and TRC flexural strength test. This research was conducted from February to June 2021 at IPB University. The flexural behavior analyzed flexural strength, ductility, and crack behavior. Ramie fiber reinforcement can improve the elasticity and ductility of mortar plates. However, woven ramie fiber with a certain woven pattern can reduce flexural strength. Coating ramie fiber with Unsaturated Polyester Resin (UPR) provides an increase in TRC flexural strength and elastic properties resulting in an increase in the ductility value. TRC cracks of UPR-coated ramie fiber underwent several phases, uncracking, crackformation, crack stabilization, and failure. The woven pattern affects the flexural behavior of the ramie fiber TRC. The woven pattern that produces the highest flexural strength is the two-axis woven pattern for UPR-coated, that is 7.84 MPa.
\end{abstract}

Keywords: concrete, flexural behaviour, ramie fiber, TRC

\section{PENDAHULUAN}

Kebutuhan terhadap beton telah meningkat seiring berkembangnya pembangunan di Indonesia. Hal tersebut dikarenakan material beton digunakan hampir di seluruh bangunan. Beton terus dikembangkan untuk menciptakan material konstruksi yang dapat digunakan di masa depan. Salah satu inovasi beton bertulang yang sedang adalah beton bertulang tekstil atau biasa dikenal dengan istilah Textile Reinforced Concrete (TRC). TRC adalah salah satu beton bertulang yang menggunakan material tekstil sebagai perkuatan untuk menambah kekuatan tarik dari beton (Gayathri et al. 2018). Berdasarkan penelitian yang telah dilakukan, diketahui bahwa TRC dapat digunakan untuk membangun struktur dengan bentuk yang lebih ramping, ringan, fleksibel, serta menghilangkan risiko kerusakan akibat korosi (Portal 2013). TRC juga dikenal sebagai material ramah lingkungan karena penggunaan tulangan tekstil yang dapat mengurangi jejak karbon dan dampak terhadap lingkungan (Portal 2013).

Penelitian dan penggunaan TRC belum banyak dilakukan di Indonesia. Hal tersebut dikarenakan material 
tekstil TRC sulit untuk didapatkan dan relatif mahal. Selain itu, teknologi dalam memproduksi tulangan tekstil belum memadai. Akan tetapi, tekstil yang berasal dari jenis serat lain memiliki potensi untuk dijadikan sebagai tulangan beton, yaitu serat alami (natural fiber). Serat alami adalah serat yang berasal dari tumbuhan atau hewan. Jenis-jenis serat dari tumbuhan antara lain kapas, pelepah pisang, enceng gondong, bambu, cantula, resam, dan rami. Sedangkan serat dari hewan misalnya wol, sutra, dan bulu unggas (Fajri et al. 2013). Di Indonesia, serat alami telah banyak diterapkan dan diteliti sebagai perkuatan material komposit dengan matriks terbuat dari polimer ataupun mortar. Salah satunya adalah penelitian yang telah dilakukan oleh Alamsyah (2017) dan Purwanto et al. (2020) mengenai pengembangan TRC menggunakan serat cantula.

Serat rami memiliki potensi untuk dijadikan perkuatan karena memiliki kekuatan tarik yang cukup tinggi. Menurut Mueller dan Krobjilobsky (2003), serat rami memiliki masa jenis sebesar 1.50-1.60 $\mathrm{g} / \mathrm{cm}^{3}$ dan kekuatan tarik berkisar 400 $1050 \mathrm{MPa}$. Serat rami mempunyai keunggulan dibandingkan serat yang lainnya seperti kekuatan tarik, daya serap terhadap air, tahan terhadap kelembapan dan bakteri, tahan terhadap panas dengan peringkat nomor dua setelah sutra dibandingkan serat alam yang lainnya, lebih ringan dibanding serat sintetis, dan ramah lingkungan. Serat rami mampu membentuk berbagai pola anyaman untuk menciptakan tekstil yang dapat digunakan sebagai perkuatan beton. Pola anyaman memiliki pengaruh terhadap kekuatan material komposit TRC (Kadir et al. 2014). Penggunaan serat rami dan pola anyaman tekstil sebagai perkuatan beton perlu diteliti lebih lanjut untuk mengetahui pengaruhnya terhadap kekuatan TRC yang dibentuk. Penelitian ini bertujuan menganalisis pengaruh perkuatan tekstil, pelapisan Unsaturated Polyester Resin (UPR), dan pola anyaman serat rami terhadap perilaku lentur pelat mortar.

\section{METODOLOGI}

Penelitian dilaksanakan pada bulan Februari hingga Juni 2021 di Institut Pertanian Bogor. Alat yang digunakan dalam penelitian ini, yaitu Universal Testing Machine (UTM), UTM Instron, satu set saringan agregat halus dan shieve shaker, oven, bekisting benda uji pelat berukuran 210 $\mathrm{mm} \times 50 \mathrm{~mm} \times 10 \mathrm{~mm}$ dan kubus berukuran $50 \mathrm{~mm} \times 50 \mathrm{~mm} \times 50 \mathrm{~mm}$, mini slump flow cone (diameter atas 60 $\mathrm{mm}$, diameter bawah $100 \mathrm{~mm}$ dan tinggi $60 \mathrm{~mm}$ ), neraca, oven, piknometer, penggaris, jangka sorong, sekop, ember, dan meteran. Adapun bahan yang dibutuhkan dalam penelitian ini adalah serat rami (CV Rabersa), semen SCC (Semen Tiga Roda), agregat halus (pasir Cimangkok), silicafume (Masterlife SF1000), superplasticizer (SikaCim Concrete Additive), air, UPR dan perekat cyanoacrylate adhesive. Secara garis besar, penelitian dilakukan melalui beberapa tahapan sebagai berikut.

\section{Pengujian Material dan Mix Design}

Pengujian material dilakukan untuk mengetahui kualitas, sifat fisik, dan sifat mekanis. Pengujian dilakukan terhadap material agregat halus dan serat rami. Perancangan mix design self-compacting mortar (SCM) dilakukan berdasarkan literatur. Selfcompacting mortar yang dirancang memiliki Faktor Air Semen (FAS) 
sebesar $\quad 0.40, \quad$ perbandingan penggunaan semen dengan pasir sebesar $1: 1.25$; kandungan silica fume $10 \%$ dari berat semen, dan superplasticizer $0.60 \%$ dari berat semen (Wibowo 2019). Perhitungan komposisi material penyusun SCM dilakukan berdasarkan persamaan perbandingan masing-masing material penyusun SCM, yaitu berdasarkan persamaan (1) - (5). Setelah itu dilakukan pengujian slump flow. Pengujian slump flow mengacu pada standar EFNARC 2005.

$$
\begin{aligned}
& V_{f m}=\frac{W_{s}}{B_{j s} B_{s a}}+\frac{W_{a}}{B_{j a} B_{s a}}+\frac{W_{s f}}{B_{j s f} B_{s a}}+ \\
& \frac{W_{p}}{B_{j p} B_{s a}}+\frac{W_{s p}}{B_{j s p} B_{s a}} \\
& W_{p}=(s / p) W_{s} \\
& W_{a}=F A S\left(D_{s f}+1\right) W_{s} \\
& W_{s p}=D_{s p} W_{s} \\
& W_{s f}=D_{s f} W_{s}
\end{aligned}
$$

Keterangan:

$V_{f m}=$ volume flow mortar $\left(\mathrm{kg} / \mathrm{m}^{3}\right)$

$W_{s} \quad=$ berat semen $(\mathrm{kg})$

$W_{a} \quad$ = berat air $(\mathrm{kg})$

$W_{s f}=$ berat silica fume $(\mathrm{kg})$

$W_{p} \quad=$ berat agregat halus $(\mathrm{kg})$

$W_{s p}=$ berat superplasticizer $(\mathrm{kg})$

$B_{s a}=$ unit weight of water $\left(\mathrm{kg} / \mathrm{m}^{3}\right)$

$B_{j s} \quad=$ berat jenis semen

$B_{j a}=$ berat jenis air

$B_{j s f}=$ berat jenis silica fume

$B_{j p} \quad=$ berat jenis agregat halus

$B_{j s p}=$ berat jenis superplasticizer

$(s / p)=$ rasio semen terhadap pasir

$F A S$ = faktor air semen

$D_{s f}=$ kadar silica fume $(\%)$

$D_{s p}=$ kadar superlasticizer $(\%)$

\section{Penganyaman dan Pelapisan UPR pada Serat Rami}

Pola anyaman yang digunakan sebagai perkuatan TRC dalam penelitian ini terdiri atas tiga macam anyaman dua dimensi, yaitu pola anyaman dua sumbu, tiga sumbu, dan empat sumbu. Setelah proses penganyaman, beberapa anyaman serat rami diberi perlakuan berbeda, yaitu dilapisi dengan Unsaturated Polyester Resin (UPR). Pelapisan UPR bertujuan sebagai upaya pengawetan dan memberikan sifat kaku serat rami sehingga pola anyaman tidak mudah berubah. Pelapisan dilakukan dengan cara mengoleskan UPR setiap permukaan serat rami kemudian didiamkan hingga lapisan UPR mengering. Hasil anyaman serat rami yang digunakan sebagai perkuatan TRC ditampilkan pada Gambar 1.

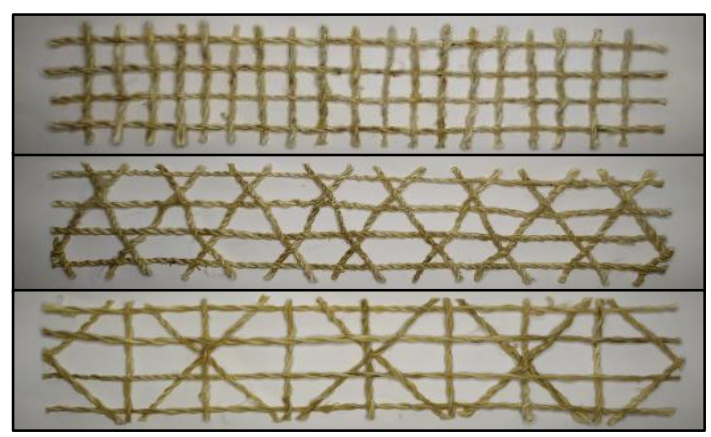

(a)

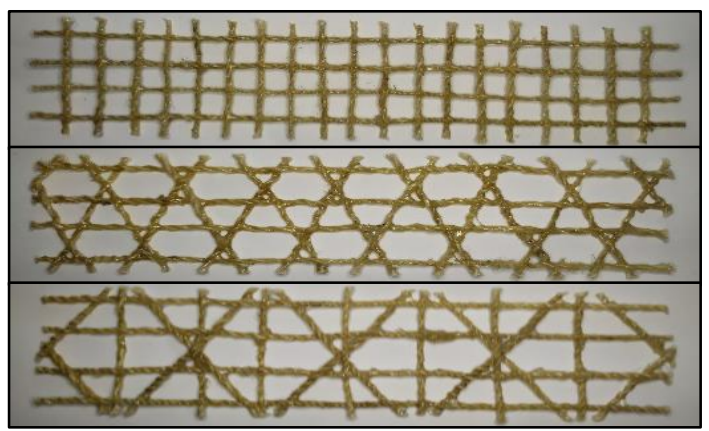

(b)

Gambar 1 Anyaman Serat Rami (a) tanpa dilapisi UPR dan (b) dilapisi UPR 


\section{Pembuatan dan Perawatan Benda Uji}

Benda uji yang dibuat yaitu berupa pelat yang memiliki dimensi panjang $210 \mathrm{~mm}$, lebar $50 \mathrm{~mm}$, dan tebal $10 \mathrm{~mm}$ ditentukan berdasarkan Alamsyah (2017) dan ASTM C947-03. Pelat TRC dicetak dengan bekisting yang terbuat dari kayu dengan dimensi yang menyesuaikan benda uji. Pelat diberi perkuatan satu lapisan anyaman serat rami yang diletakkan tepat di tengah dari ketebalan pelat. Jumlah benda uji pelat TRC yang dibuat adalah sebanyak 21 buah. Hasil benda uji pelat TRC seperti yang ditampilkan pada Gambar 2. Selain pelat TRC, benda uji mortar berbentuk kubus bersisi $50 \mathrm{~mm}$ dibuat untuk pengujian kuat tekan mortar. Selanjutnya adalah proses perawatan (curing) dengan cara menutup benda uji menggunakan kain basah hingga waktu pengujian kuat lentur, yaitu setelah berumur 28 hari.

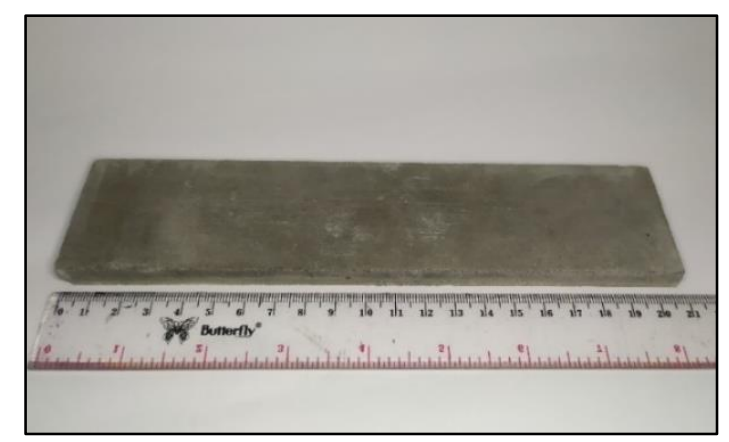

Gambar 2 Benda Uji Pelat TRC

\section{Pengujian Mortar dan TRC}

Pengujian kuat tekan dan kuat lentur dilakukan terhadap benda uji yang telah berumur 28 hari. Pengujian kuat tekan mengacu pada SNI 03-68252002 sedangkan pengujian lentur mengacu pada dan ASTM C947-03. Alat yang digunakan dalam pengujian kuat lentur adalah UTM Instron. Pembebanan diberikan secara konstan dengan kecepatan 4 detik/mm. Pembebanan dilakukan hingga beban maksimal yang ditandai dengan runtuhnya benda uji. Persamaan yang digunakan dalam menghitung kuat tekan mortar adalah sebagai berikut.

$f^{\prime} c=\frac{P}{A}$

Keterangan:

$f^{\prime} c=$ kuat tekan, $\mathrm{MPa}$

$P \quad=$ beban ultimit, $\mathrm{N}$

$\mathrm{A}=$ luas penampang, $\mathrm{mm}^{2}$

\section{Pengolahan dan Analisis Data}

Perilaku non-linier TRC biasanya ditandai dengan cara lentur (Yin et al. 2013), tarik (Colombo et al. 2013) dan uji pull-out (Lorenz et al. 2013). Perilaku lentur merupakan kemampuan mekanik suatu struktur dalam menahan beban yang yang bekerja di antara tumpuan (Alamsyah et al. 2017). Perilaku lentur terdiri atas kuat lentur (flexural strength), kekakuan (stiffness), daktilitas (ductility), dan perilaku retak (crack behavior).

Kekakuan merupakan kemampuan suatu elemen untuk dapat bersifat tidak elastis atau kaku. Daktilitas adalah kemampuan suatu material dalam mengembangkan regangan pada saat mengalami retak pertama atau kondisi leleh hingga mengalami runtuh (Alamsyah et al. 2017). Kuat lentur atau modulus of rupture, kekauan, dan daktilitas dapat dihitung berdasarkan persamaan (7), (8), dan (9).

$$
\begin{aligned}
\text { Kuat lentur } & =\frac{P L}{b d^{2}} \ldots \ldots . . . \\
\text { Kekakuan } & =\frac{P}{\delta} \ldots \ldots \ldots \ldots . . . . . \\
\text { Daktilitas } & =\frac{\delta_{\text {ultimit }}}{\delta_{\text {leleh }}}
\end{aligned}
$$

Keterangan:

$l \quad=$ panjang bentang, $\mathrm{mm}$

$P \quad=$ beban ultimit, $\mathrm{N}$ 
$b \quad=$ lebar benda uji, $\mathrm{mm}$

$d \quad=$ tebal benda uji, $\mathrm{mm}$

$\delta_{\text {ultimit }}=$ lendutan saat beban ultimit, $\mathrm{mm}$

$\delta_{\text {leleh }}=$ lendutan leleh, $\mathrm{mm}$

Perilaku retak atau crack behavior dalam TRC atau beton bertulang konvensional berdasarkan grafik hubungan antara beban dan lendutan dapat digambarkan menjadi empat state atau fase (Brameshuber 2006). Fase I atau uncracked concrete merupakan kondisi yang menggambarkan perilaku elastis penuh dari beton. Fase IIA atau crack formation terjadi ketika terjadi retakan pertama hingga multiple cracking dengan peningkatan beban yang rendah sedangkan pada fase IIB atau crack stabilization pembentukan retakan menjadi stabil. Fase III menggambarkan kondisi daktail setelah perkuatan tekstil mengalami batas kuat tariknya.

Prosedur pelaksanaan penelitian disajikan dalam diagram alir berikut.

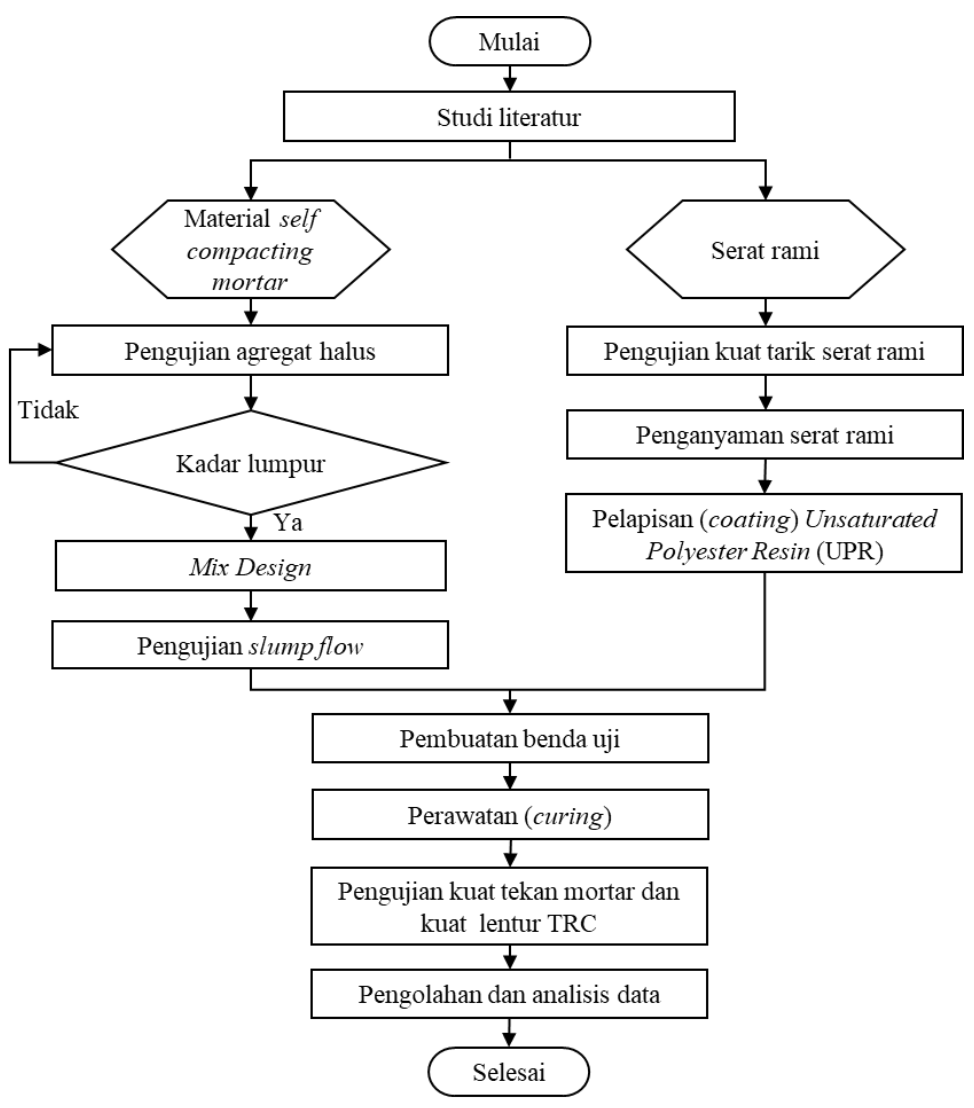

Gambar 3 Diagram Alir Penelitian

\section{HASIL DAN PEMBAHASAN}

\section{Self-Compacting Mortar}

Karakteristik material merupakan hal yang sangat penting dalam proses perencanaan campuran mortar. Berdasarkan analisis saringan, pasir Cimangkok termasuk ke dalam kategori gradasi nomor 2 dengan nilai modulus kehalusan sebesar 3.59. Kadar lumpur agregat halus hasil pengujian sebesar $1.65 \%$. Berat jenis dalam kondisi Saturated Surface Dry (SSD) sebesar 2.58. Kadar air dan adsorpsi agregat halus sebesar $1.53 \%$ dan 
3.14\%. Karakteristik agregat halus hasil pengujian memenuhi standar yang berlaku baik berdasarkan SNI maupun ASTM. Semen yang digunakan dalam campuran mortar memiliki nilai berat jenis rata-rata sebesar 3.00. Berat jenis silica fume dan superplasticizer yang digunakan bedasarkan informasi yang diberikan oleh produsen adalah sebesar 2.20 dan 1.17.

Campuran mortar dirancang berdasarkan penelitian yang telah dilakukan sebelumnya oleh Wibowo (2019). Perancangan campuran mortar dilakukan dengan menentukan berat material berdasarkan persamaan perbandingan berat dari masingmasing material penyusun. Hasil dari perhitungan kemudian dikoreksi terhadap kadar air yang terkandung di dalam agregat halus. Hasil perhitungan mix design untuk $1.00 \mathrm{~m}^{3}$ mortar ditampilkan pada tabel berikut.

Tabel 1 Mix design untuk $1.00 \mathrm{~m}^{3}$ Mortar

\begin{tabular}{lcc}
\hline \multicolumn{1}{c}{ Material } & Jumlah & Satuan \\
\hline Semen & 764.50 & $\mathrm{~kg}$ \\
Agregat halus & 932.97 & $\mathrm{~kg}$ \\
Air & 359.04 & $\mathrm{~m}^{3}$ \\
Silica Fume & 76.45 & $\mathrm{~kg}$ \\
Superplasticizer & 4.59 & $\mathrm{~kg}$ \\
\hline
\end{tabular}

Kualitas mortar dapat diketahui berdasarkan hasil uji mortar segar dan kuat tekan 28 hari. Pengujian terhadap mortar segar yang dilakukan adalah uji slump flow. Nilai slump flow yang dihasilkan sebesar $260 \mathrm{~mm}$. Nilai tersebut memenuhi rentang slump flow yang disyaratkan dalam EFNARC (2005) sebesar 240-260 mm. Berdasarkan hasil pengujian, kuat tekan rata-rata mortar didapatkan sebesar 50.05 MPa. Nilai tersebut masih di bawah nilai yang tercantum dalam Wibowo (2019). Perbedaan kuat tekan yang dihasilkan dapat dikarenakan perbedaan karakteristik dan kualitas material yang digunakan. Nilai berat jenis rata-rata mortar yang dihasilkan sebesar $2015.62 \mathrm{~kg} / \mathrm{m}^{3}$.

\section{Hasil Pengujian Serat Rami}

Berat jenis rata-rata serat rami yang diuji sebesar $1.50 \mathrm{~g} / \mathrm{cm}^{3}$. Nilai tersebut sesuai dengan literatur nilai berat jenis yang disebutkan dalam Schuh dan Gayer (1997) serta Mueller dan Krobjilobsky (2003), yaitu berkisar $1.50-1.60 \mathrm{~g} / \mathrm{cm}^{3}$. Kadar air yang terkandung di dalam serat rami yaitu $13.26 \%$ dari berat kering serat. Diameter rata-rata serat rami sebesar $1.40 \mathrm{~mm}$. Serat rami yang digunakan terdiri atas dua helai atau ply yang dipilin menjadi tali. Nilai kuat tarik serat rami yang dihasilkan sebesar 122.97 MPa. Namun nilai tersebut masih lebih rendah jika dibandingkan dengan literatur. Menurut Mueller dan Krobjilobsky (2003), Rahardjo (2008), dan Naidu et al. (2017) nilai kuat tarik serat rami berkisar 220-1050 MPa. Rendahnya serta tidak sesuainya kuat tarik serat rami dibandingkan literatur dapat diakibatkan oleh perbedaan kualitas antar kedua helai benang rami. Saat tali rami mencapai kuat tarik ultimitnya, tidak menyebabkan kedua ply benang rami putus.

\section{Hasil Pengujian Pelat TRC}

Pengujian yang dilakukan terhadap benda uji pelat TRC adalah uji berat isi atau densitas dan uji lentur. Nilai densitas atau berat isi didapatkan dengan membagi massa dengan volume dari masing-masing benda uji. Pengujian lentur menghasikan kurva hubungan antara beban dan lendutan. Perilaku lentur yang dianalisis, antara lain kuat lentur, kekakuan, daktilitas, dan perilaku retak (crack behaviour). Notasi serta nilai densitas masingmasing benda uji ditampilkan dalam tabel berikut. 
Tabel 2 Notasi dan Densitas Benda Uji Pelat

\begin{tabular}{|c|c|c|c|c|c|}
\hline No. & Benda Uji TRC & Notasi & & Densitas $\left(\mathrm{kg} / \mathrm{m}^{3}\right)$ & $\begin{array}{l}\text { Densitas Rata-rata } \\
\qquad\left(\mathrm{kg} / \mathrm{m}^{3}\right)\end{array}$ \\
\hline \multirow{3}{*}{1} & \multirow{3}{*}{ Tanpa perkuatan/pelat mortar } & \multirow{3}{*}{ TRC 0} & $\mathrm{a}$ & 2018.32 & \multirow{3}{*}{2015.74} \\
\hline & & & $\mathrm{b}$ & 2023.81 & \\
\hline & & & $\mathrm{c}$ & 2005.08 & \\
\hline \multirow{3}{*}{2} & \multirow{3}{*}{ Anyaman dua sumbu } & \multirow{3}{*}{ TRC 1A } & $\mathrm{a}$ & 1901.31 & \multirow{3}{*}{1912.55} \\
\hline & & & $\mathrm{b}$ & 1921.28 & \\
\hline & & & $\mathrm{c}$ & 1915.07 & \\
\hline \multirow{3}{*}{3} & \multirow{3}{*}{ Anyaman tiga sumbu } & \multirow{3}{*}{ TRC 2A } & $\mathrm{a}$ & 1927.46 & \multirow{3}{*}{1922.18} \\
\hline & & & $\mathrm{b}$ & 1923.37 & \\
\hline & & & $\mathrm{c}$ & 1915.73 & \\
\hline \multirow{3}{*}{4} & \multirow{3}{*}{ Anyaman empat sumbu } & \multirow{3}{*}{ TRC 3A } & $\mathrm{a}$ & 1993.54 & \multirow{3}{*}{1983.43} \\
\hline & & & $\mathrm{b}$ & 1988.31 & \\
\hline & & & $\mathrm{c}$ & 1968.45 & \\
\hline \multirow{3}{*}{5} & \multirow{3}{*}{$\begin{array}{l}\text { Anyaman dua sumbu } \\
\text { terlapisi UPR }\end{array}$} & \multirow{3}{*}{ TRC 1B } & $\mathrm{a}$ & 1900.06 & \multirow{3}{*}{1919.81} \\
\hline & & & $\mathrm{b}$ & 1914.25 & \\
\hline & & & $\mathrm{c}$ & 1945.14 & \\
\hline \multirow{3}{*}{6} & \multirow{3}{*}{$\begin{array}{l}\text { Anyaman tiga sumbu } \\
\text { terlapisi UPR }\end{array}$} & \multirow{3}{*}{ TRC 2B } & $\mathrm{a}$ & 1927.26 & \multirow{3}{*}{1939.90} \\
\hline & & & $\mathrm{b}$ & 1970.26 & \\
\hline & & & $\mathrm{c}$ & 1922.16 & \\
\hline \multirow{3}{*}{7} & \multirow{3}{*}{$\begin{array}{l}\text { Anyaman empat sumbu } \\
\text { terlapisi UPR }\end{array}$} & \multirow{3}{*}{ TRC 3B } & $\mathrm{a}$ & 1886.87 & \multirow{3}{*}{1887.68} \\
\hline & & & $\mathrm{b}$ & 1897.57 & \\
\hline & & & $\mathrm{c}$ & 1878.60 & \\
\hline
\end{tabular}

Pelat mortar tanpa perkuatan serat rami memiliki densitas rata-rata sebesar $2015.74 \mathrm{~kg} / \mathrm{m}^{3}$. Nilai densitas pelat ini relatif sama dengan nilai densitas mortar rata-rata. Hal tersebut diakibatkan oleh pelat tidak diberikan serat rami sebagai perkuatan sehingga hanya tersusun oleh mortar. Benda uji pelat TRC serat rami tanpa dilapisi UPR memiliki nilai densitas sebesar 1901.31-1993.54 kg/m ${ }^{3}$ dengan nilai rata-rata tertinggi terjadi pada pola anyaman empat sumbu. Sedangkan benda uji pelat TRC serat rami terlapisi UPR memiliki nilai densitas sebesar 1886.87-1970.26 kg/m ${ }^{3}$ dengan nilai rata-rata tertinggi terjadi pada pola anyaman tiga sumbu. Dibandingkan dengan beton normal, TRC dalam penelitian ini memiliki nilai densitas yang lebih rendah. Berdasarkan SNI 03-2834-2000, beton normal memiliki densitas sebesar $2200-2500 \mathrm{~kg} / \mathrm{m}^{3}$.

Kurva hubungan antara beban dan lendutan hasil pengujian lentur terhadap tujuh perlakuan benda uji yang masing-masing terdiri atas tiga buah sampel disajikan pada Gambar 4 hingga Gambar 6.

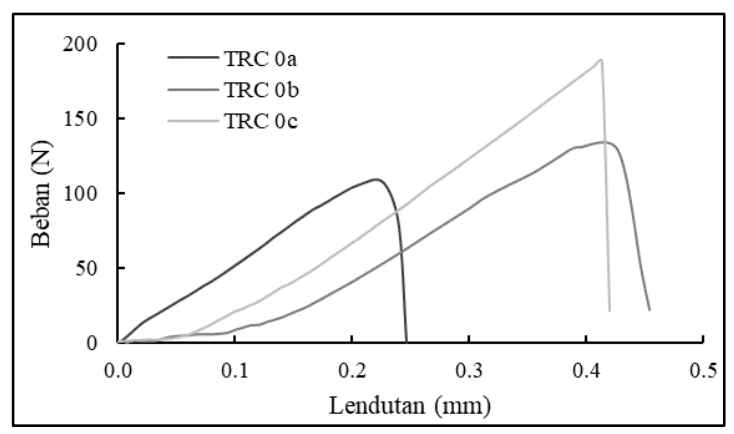

Gambar 4 Kurva Hubungan BebanLendutan Pelat Mortar Tanpa Serat Rami

Berdasarkan Gambar 4, pelat mortar yang tidak diberi perkuatan memiliki bentuk kurva hubungan beban dan lendutan yang berbeda antar ketiga sampel. Namun, ketiga sampel sama-sama mengalami keruntuhan pada saat terjadinya retakan pertama. Terjadinya retakan pada pelat TRC 
ditandai dengan penurunan beban yang signifikan pada kurva beban-lendutan. Nilai beban ultimit yang dicapai sampel TRC 0a, TRC 0b, dan TRC 0c secara berturut-turut adalah 106.05, 130.62, dan $188.05 \mathrm{~N}$.

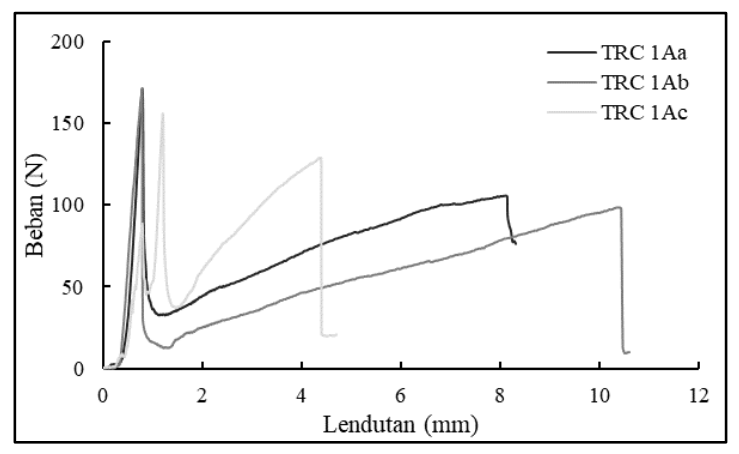

(a)

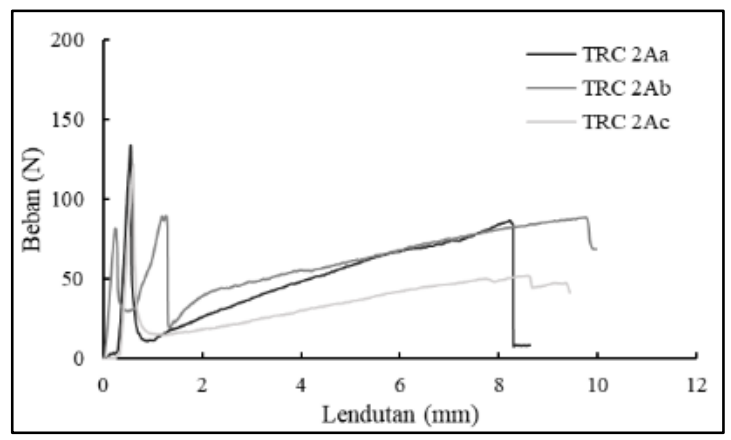

(b)

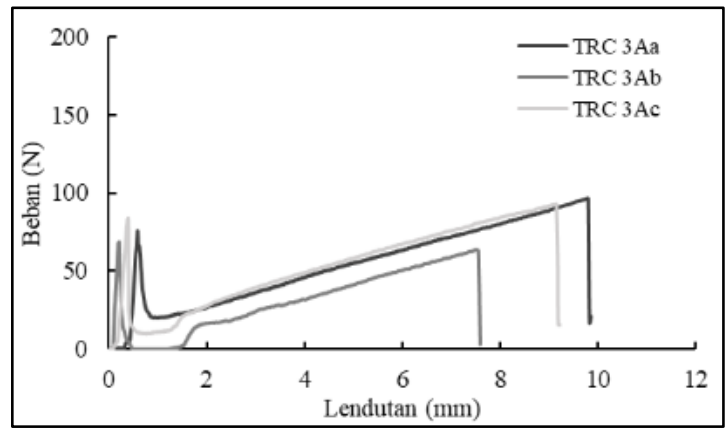

(c)

Gambar 5 Kurva Hubungan BebanLendutan TRC Serat Rami Tanpa dilapisi UPR dengan Pola Anyaman a) Dua Sumbu, b) Tiga Sumbu, dan c) Empat Sumbu
Gambar 5(a) memperlihatkan nilai beban ultimit yang dicapai sampel TRC 1Aa, TRC 1Ab, dan TRC 1Ac secara berturut-turut adalah 171.24, 171.06, dan 156.21 N dengan nilai lendutan sebesar 0.79, 0.78, dan 1.20 $\mathrm{mm}$. Nilai beban ultimit tertinggi terjadi pada sampel TRC 1Aa sedangkan nilai beban ultimit terendah terjadi pada sampel TRC 1Ac. Berdasarkan Gambar 5(b), nilai beban ultimit yang dicapai sampel TRC 2Aa, TRC 2Ab, dan TRC 2Ac secara berturut-turut adalah 133.58, 89.40, dan 121.78 N. Nilai lendutan yang terjadi saat mencapai beban ultimit dari ketiga sampel adalah $0.55,1.25$, dan $0.60 \mathrm{~mm}$. TRC dengan pola anyaman empat sumbu memiliki nilai beban ultimit di bawah $100 \mathrm{~N}$, yaitu sebesar 96.56, 68.36, dan 92.61 N.

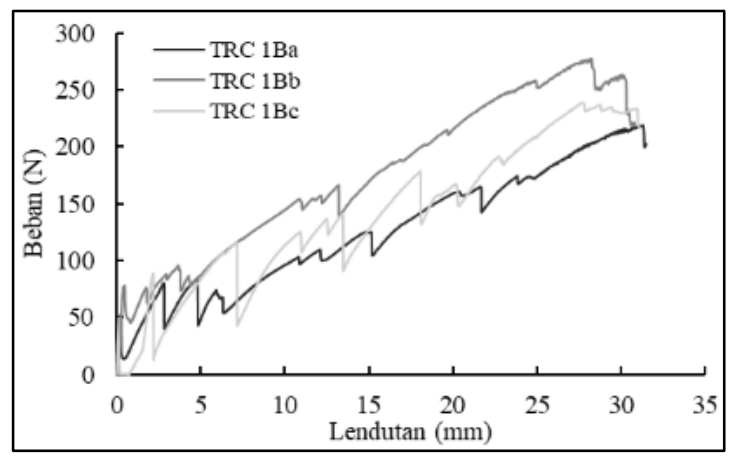

(a)

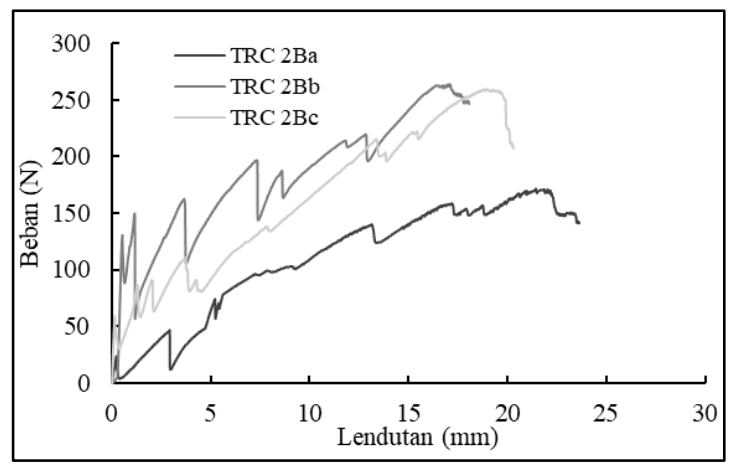

(b) 


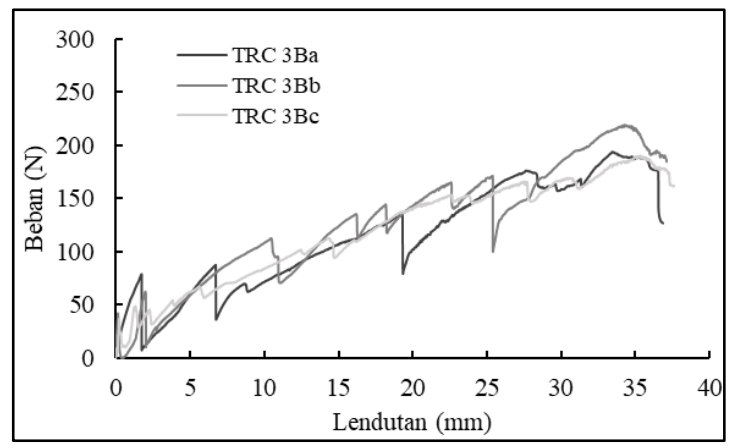

(c)

Gambar 6 Kurva Hubungan BebanLendutan TRC Serat Rami Terlapisi UPR dengan Pola Anyaman a) Dua Sumbu, b) Tiga Sumbu, dan c) Empat Sumbu

Berdasarkan Gambar 6(a), nilai beban ultimit sampel TRC 1Ba, TRC $1 \mathrm{Bb}$, dan TRC $1 \mathrm{Bc}$ secara berturutturut sebesar 218.87, 278.13 dan 238.99 N. Nilai tersebut terjadi ketika besarnya lendutan masing-masing sampel mencapai 31.30, 28.20, dan $27.73 \mathrm{~mm}$. Sampel TRC 2Ba, TRC 2Bb, dan TRC 2Bc memiliki nilai beban ultimit masing-masing sebesar 170.99, 263.53, dan $259.76 \mathrm{~N}$. Berdasarkan Gambar 6 (c), sampel TRC 3Ba, TRC 3Bb, dan TRC 3Bc memiliki nilai beban ultimit masingmasing sebesar 193.62, 219.36, dan 190.89 N. Nilai lendutan ultimit dari ketiga sampel tidak berbeda jauh, yaitu sebesar 33.42, 34.23, dan $35.35 \mathrm{~mm}$.

Perbedaan pola anyaman dan perlakuan pelapisan UPR serat rami berpengaruh terhadap bentuk kurva hubungan beban-lendutan serta nilai yang dicapainya. Perbedaan pola anyaman mengakibatkan perbedaan nilai beban ultimit dan lendutan yang dicapai. Pola anyaman dua sumbu mencapai beban ultimit yang lebih tinggi dibandingkan kedua pola anyaman lainnya. Pelat TRC yang diperkuat dengan serat rami tanpa dilapisi dengan UPR rata-rata mengalami keruntuhan pada keretakan yang kedua. Sedangkan pelat TRC yang diperkuat dengan serat rami terlapisi UPR mengalami keruntuhan setelah terjadi beberapa retakan sehingga lendutan yang terjadi lebih tinggi dibandingkan dengan pelat TRC lainnya atau bersifat pseudo-ductile.

Hasil perhitungan nilai kuat lentur, kekakuan, dan daktilitas setiap benda uji berdasarkan pengujian lentur dengan dua titik pembebanan ditampilkan pada gambar berikut.

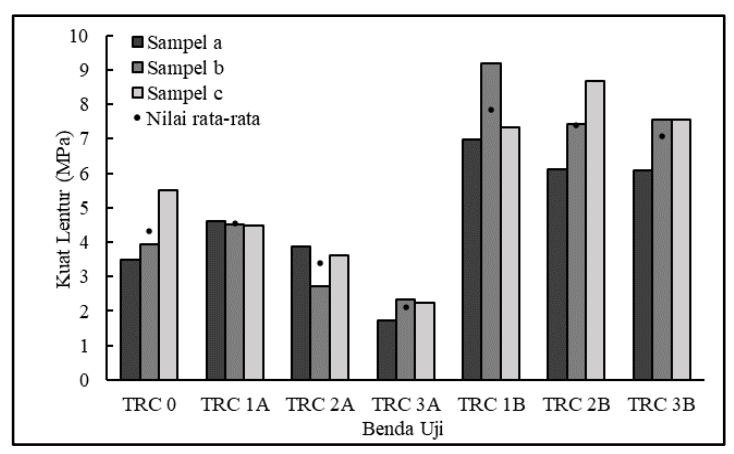

Gambar 7 Nilai Kuat Lentur Setiap Benda Uji Pelat TRC

Pelat mortar yang tidak diberikan perkuatan memiliki nilai kuat lentur sekitar 3.48-5.51 MPa. TRC serat rami tanpa dilapisi UPR memiliki kuat lentur sebesar 1.74-4.60 MPa dengan nilai rata-rata tertinggi terjadi pada pola anyaman dua sumbu. Sedangkan TRC serat rami yang terlapisi UPR memiliki kuat lentur sebesar 6.09-9.20 MPa. Sama halnya seperti TRC serat rami tanpa dilapisi UPR, nilai kuat lentur rata-rata tertinggi terjadi pada pola anyaman dua sumbu. 
Tabel 3 Persentase Peningkatan Nilai Kuat Lentur Rata-rata

\begin{tabular}{ccc}
\hline $\begin{array}{c}\text { Benda } \\
\text { Uji }\end{array}$ & $\begin{array}{c}\text { Peningkatan } \\
\text { Akibat } \\
\text { Perkuatan } \\
(\%)\end{array}$ & $\begin{array}{c}\text { Peningkatan } \\
\text { Akibat } \\
\text { Pelapisan UPR } \\
(\%)\end{array}$ \\
\hline $\begin{array}{c}\text { TRC } 0 \\
\text { TRC }\end{array}$ & - & - \\
1A & 5.20 & - \\
TRC & -21.09 & - \\
2A & & \\
TRC & -51.24 & - \\
3A & & 72.80 \\
TRC & 81.79 & 117.61 \\
1B & & \\
TRC & 71.72 & 235.85 \\
2B & & \\
TRC & 63.77 & \\
3B & &
\end{tabular}

Berdasarkan Gambar 7 dan

Tabel 3, pemberian perkuatan tekstil berupa anyaman serat rami dapat meningkatkan dan juga menurunkan kuat lentur dibandingkan dengan pelat mortar tanpa perkuatan. TRC yang tidak diberikan perkuatan memiliki nilai kuat lentur rata-rata sebesar 4.31 MPa. Jika dibandingkan dengan pelat TRC tanpa perkuatan, peningkatan kuat lentur rata-rata yang terjadi sebesar $5.20-81.79 \%$, kecuali pada TRC 2A dan 3A. Pengaruh pelapisan UPR mengakibatkan kenaikan kuat lentur berkisar antara 72.80-235.85\%. Penambahan jumlah sumbu anyaman menyebabkan penurunan nilai kuat lentur. Pola anyaman yang memiliki nilai kuat lentur rata-rata tertinggi terjadi pada pola anyaman dua sumbu.
Kekakuan didefinisikan sebagai gaya yang diperlukan untuk memperoleh satu satuan lendutan (Ujianto 2006). Kekakuan dihitung berdasarkan data beban dan lendutan ultimit. Berikut ini merupakan hasil perhitungan nilai kekakuan setiap benda uji TRC.

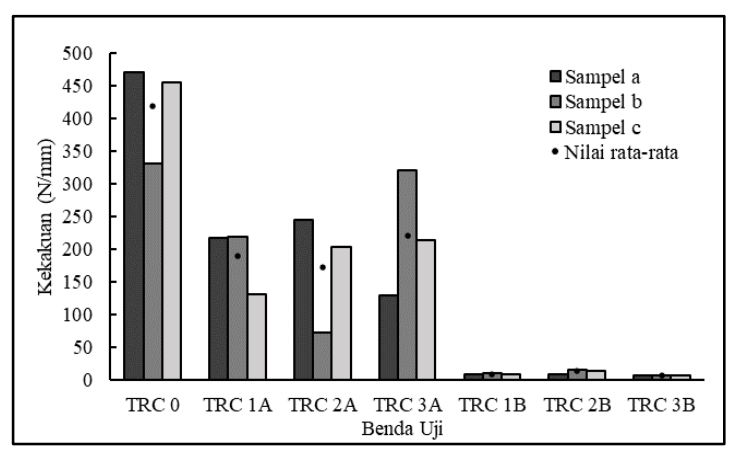

Gambar 8 Nilai Kekakuan Setiap Benda Uji Pelat TRC

Setiap benda uji memiliki nilai kekakuan yang bervariasi. Nilai kekakuan rata-rata tertinggi dimiliki oleh pelat mortar tanpa perkuatan (TRC 0), yaitu sebesar $419.28 \mathrm{~N} / \mathrm{mm}$. Nilai kekakuan TRC serat rami tanpa dilapisi UPR berkisar 71.33-320.20 $\mathrm{N} / \mathrm{mm}$. Sedangkan TRC serat rami yang terlapisi UPR memiliki nilai kekakuan yang jauh lebih rendah, yaitu berkisar 5.40-15.42 N/mm.

Tabel 4 Persentase Penurunan Nilai Kekakuan Rata-rata

\begin{tabular}{ccc}
\hline $\begin{array}{c}\text { Benda } \\
\text { Uji }\end{array}$ & $\begin{array}{c}\text { Penurunan } \\
\text { Akibat } \\
\text { Perkuatan } \\
(\%)\end{array}$ & $\begin{array}{c}\text { Penurunan } \\
\text { Akibat } \\
\text { Pelapisan UPR } \\
(\%)\end{array}$ \\
\hline $\begin{array}{c}\text { TRC } 0 \\
\text { TRC }\end{array}$ & - & - \\
1A & 54.91 & - \\
TRC & 58.77 & - \\
2A & & \\
TRC & 47.29 & - \\
3A & & \\
TRC & 97.97 & 95.51 \\
1B & & \\
TRC & 97.05 & 92.85 \\
2B & 98.60 & 97.34 \\
TRC & & \\
\hline
\end{tabular}


3B

Nilai kekakuan TRC yang diberi perkuatan tekstil memiliki nilai yang lebih rendah dibandingkan tanpa diberi perkuatan. Dalam arti lain, perkuatan tekstil mampu meningkatkan elastisitas TRC. Berdasarkan

Tabel 4, penurunan nilai kekakuan rata-rata yang terjadi sebesar 47.29-98.60\% dibandingkan dengan pelat mortar tanpa serat rami, dengan kekakuan terendah terjadi pada pola anyaman tiga sumbu. Perkuatan tekstil yang ada di dalam TRC mampu menahan retakan yang terjadi saat dikenakan beban. Perkuatan memberikan sifat elastis kepada pelat TRC beton yang memiliki elastisitas yang rendah. Selain itu, pelapisan UPR juga dapat meningkatkan elastisitas lentur TRC. Penurunan nilai kekakuan rata-rata yang dihasilkan sebesar 92.85-97.34\% dibandingkan dengan TRC serat rami yang tanpa dilapisi UPR, dengan kekakuan terendah terjadi pada pola anyaman empat sumbu. Perbedaan pola anyaman tidak memberikan pengaruh yang sama antara TRC serat rami yang tanpa dilapisi dan dilapisi UPR, nilai yang dihasilkan lebih bervariasi.

Daktilitas menyatakan suatu kemampuan dari struktur untuk mengalami lendutan yang besar tanpa mengalami penurunan kekuatan yang berarti (Nurlina 2016). Nilai daktilitas didefinisakan sebagai perbandingan besar lendutan ultimit dengan lendutan leleh pertama. Dalam penelitian ini, lendutan ultimit merupakan nilai lendutan yang terjadi ketika mencapai beban maksimum. Sedangakan lendutan leleh pertama didapatkan ketika TRC mengalami retak pertama. Berikut ini merupakan hasil perhitungan nilai daktilitas yang ditampilkan dalam

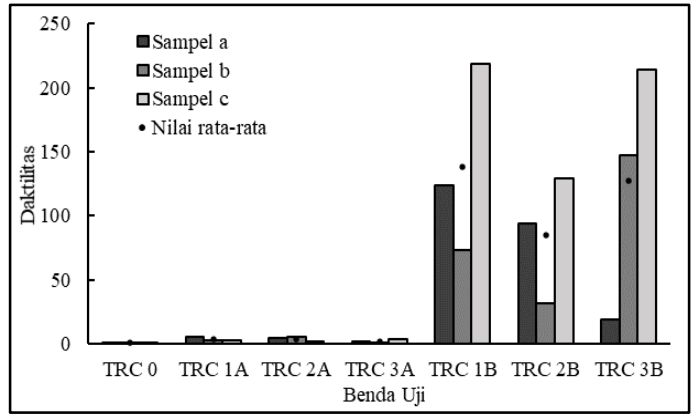

Gambar 9.

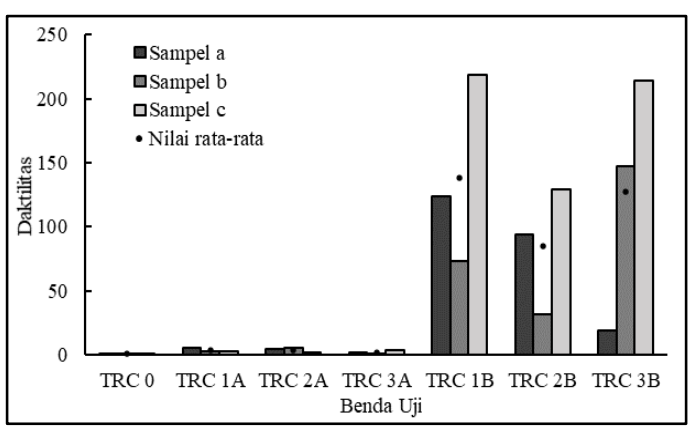

Gambar 9 Nilai daktilitas setiap benda uji pelat TRC

Pelat mortar memiliki nilai daktilitas yang sama antar ketiga ulangan, yaitu sebesar 1.00. Nilai daktilitas 1TRC serat rami tanpa dilapisi UPR memiliki nilai daktilitas 1.10-5.37 dengan nilai daktilitas ratarata tertinggi terjadi pada pola anyaman tiga sumbu. Sedangkan pada TRC serat rami yang terlapisi UPR memiliki nilai daktilitas 32.05-218.86 dengan nilai daktilitas rata-rata tertinggi terjadi pada pola anyaman dua sumbu.

Tabel 5 Persentase Peningkatan Nilai

\begin{tabular}{ccc}
\multicolumn{3}{c}{ Daktilitas Rata-rata } \\
\hline $\begin{array}{c}\text { Benda } \\
\text { Uji }\end{array}$ & $\begin{array}{c}\text { Peningkatan } \\
\text { Akibat } \\
\text { Perkuatan } \\
(\%)\end{array}$ & $\begin{array}{c}\text { Peningkatan } \\
\text { Akibat } \\
\text { Pelapisan UPR } \\
(\%)\end{array}$ \\
\hline $\begin{array}{c}\text { TRC 0 } \\
\text { TRC }\end{array}$ & - & - \\
1A & 274.13 & - \\
TRC & 298.05 & - \\
2A & & - \\
TRC & 100.39 & - \\
3A & &
\end{tabular}




\begin{tabular}{ccc} 
TRC & 13745.44 & 3600.73 \\
1B & & \\
TRC & 8406.73 & 2114.29 \\
2B & & \\
TRC & 12595.32 & 6235.40 \\
3B & 1250 \\
\hline
\end{tabular}

Berdasarkan nilai daktilitas ratarata terendah terjadi pada pelat mortar tanpa serat rami. Perkuatan serat rami memberikan peningkatan nilai daktilitas. Pelapisan UPR mampu memberikan peningkatan yang tinggi terhadap nilai daktilitas pada TRC. Peningkatan daktilitas yang terjadi jika dibandingkan dengan pelat mortar tanpa serat rami sebesar 100.39$13745.44 \%$ seperti yang disajikan dalam

Tabel 5. Sedangkan peningkatan nilai daktilitas TRC akibat adanya pelapisan UPR dibandingkan tanpa pelapisan UPR sebesar 2114.29$6235.40 \%$. TRC mampu menerima beban yang lebih tinggi meskipun telah terjadi beberapa retakan sehingga menyebabkan nilai daktilitas yang tinggi. Hal tersebut menjadi salah satu sifat serta keuntungan dari TRC yang mampu menoleransi terjadinya retakan. Mechtcherin (2013) menyatakan bahwa keuntungan utama dari TRC adalah kuat tarik yang tinggi serta sifat peudo-ductile, yang mampu menoleransi beberapa retakan yang terjadi.

Berdasarkan hasil pengujian, setiap benda uji memiliki perilaku retak yang beragam. Perilaku retak berdasarkan kurva hubungan antara beban dan lendutan serta pola retakan benda uji dapat dilihat pada gambar berikut.
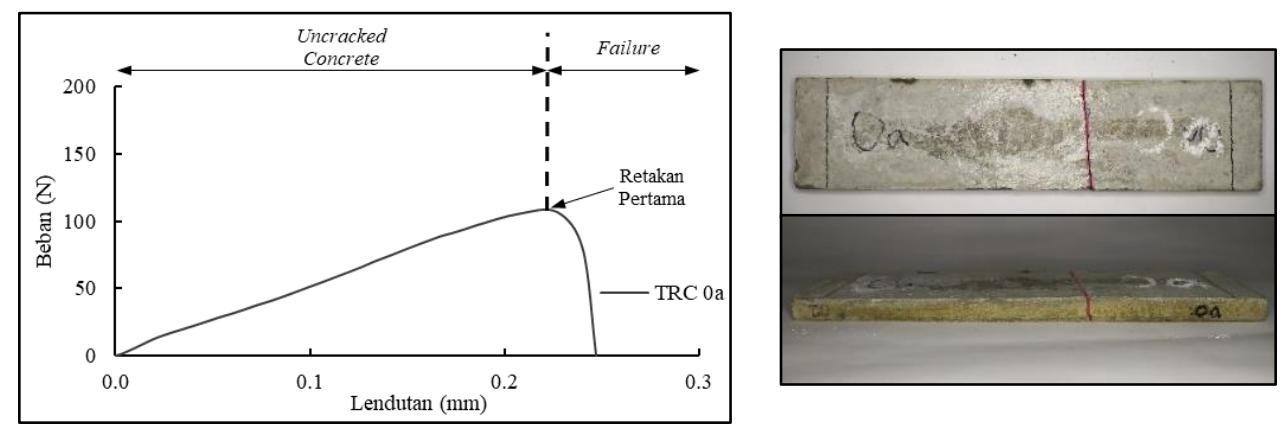

Gambar 10 Crack behaviour Pelat Mortar Tanpa Perkuatan Serat Rami
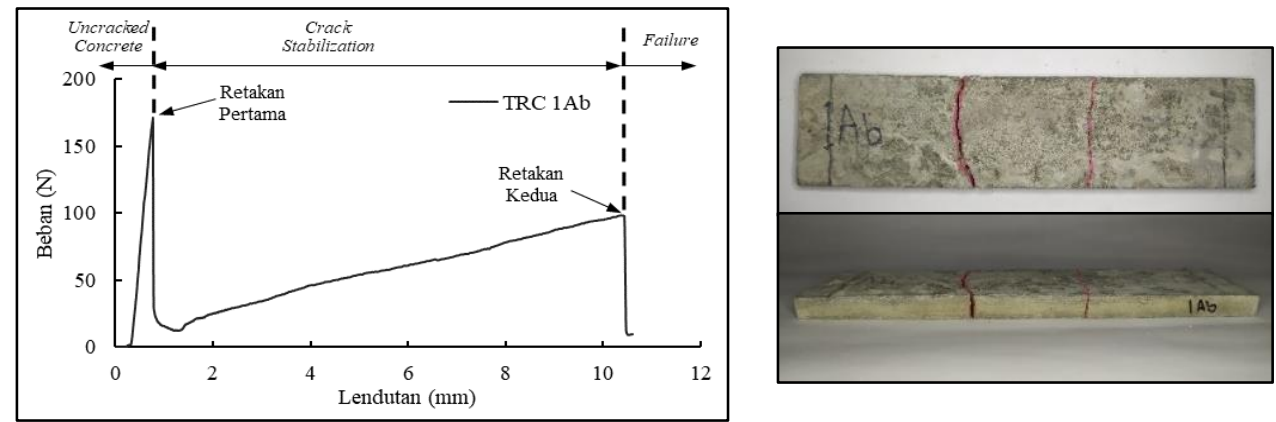

Gambar 11 Crack behaviour Pelat TRC dengan Perkuatan Serat Rami Tanpa Dilapisi UPR 

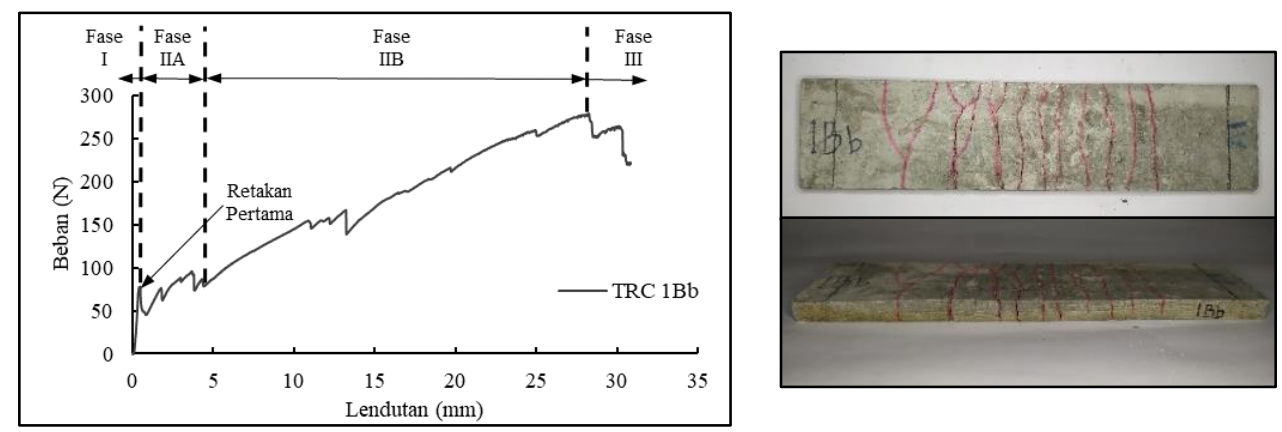

Gambar 12 Crack behaviour Pelat TRC dengan Perkuatan Serat Rami Terlapisi UPR

Pelat TRC dengan perkuatan serat rami tanpa dilapisi UPR memiliki perilaku retak yang sangat berbeda dengan benda uji sebelumnya. Pola anyaman dua, tiga, maupun empat sumbu memberikan perilaku retak pelat TRC yang relatif sama. Pola retak yang terjadi adalah pola retak lentur atau flexural crack. Berdasarkan kurva hubungan beban-lendutan, terdapat empat fase yang terjadi dari awal pelat menerima beban hingga terjadinya keruntuhan. Fase pertama merupakan fase I atau fase uncrack concrete, yaitu kondisi saat beton belum mengalami retak. Pada fase ini, kekuatan pelat bergantung kepada kekakuan mortar. Apabila mortar sudah tidak dapat menahan beban lentur yang terjadi maka akan terjadi keretakan yang pertama dan memasuki fase selanjutnya.

Fase selanjutnya adalah fase keretakan, yang terdiri atas fase IIA atau fase crack formation dan fase IIB atau fase crack stabilization. Fase IIA merupakan kondisi dimana TRC mengalami beberapa keretakan akibat pembebanan yang terjadi. Setelah mengalami retak pertama, perkuatan serat rami akan menahan tepat di titik terjadinya retakan tersebut hingga terjadi keretakan berikutnya sehingga TRC tidak mengalami keruntuhan atau masih dapat menerima beban lentur yang lebih tinggi. Jumlah retakan yang terjadi dalam fase ini sangat bervariasi antar pola anyaman. Menurut Portal
(2013), setelah mengalami pembentukan beberapa retakan kemudian akan mengalami penstabilan retakan-retakan yang sudah terjadi (fase IIB atau fase crack stabilization) sehingga TRC mampu menerima pertambahan beban yang lebih besar tanpa menciptakan retakan baru. Akan tetapi, pada fase IIB dalam penelitian ini terjadi beberapa retakan baru. Hal tersebut dapat terjadi akibat pengaruh posisi perkuatan serat terhadap ketebalan pelat. Penempatan posisi perkuatan serat terhadap ketebalan pelat akan mempengaruhi distribusi beban yang diterima.

\section{KESIMPULAN}

Berdasarkan penelitian yang telah dilakukan, dapat ditarik kesimpulan bahwa:

1. Perkuatan serat rami dapat meningkatkan elastisitas dan daktilitas pelat mortar. Akan tetapi, anyaman serat rami dengan pola anyaman tertentu dapat menurunkan kuat lentur. Penurunan kuat lentur terjadi pada TRC serat rami dengan pola anyaman tiga dan empat sumbu tanpa terlapisi UPR.

2. Pelapisan serat rami dengan Unsaturated Polyester Resin (UPR) memberikan pengaruh yang signifikan terhadap perilaku lentur TRC serat rami. Pelapisan UPR memberikan peningkatan kuat lentur TRC dan sifat elastis sehingga terjadi 
peningkatan nilai daktilitas. Perilaku retak TRC serat rami yang terlapisi UPR mengalami beberapa fase, yiatu fase sebelum keretakan, pembentukan beberapa retakan, penstabilan retakan, dan keruntuhan.

3. Pola anyaman berpengaruh terhadap perilaku lentur TRC serat rami. Pola anyaman yang menghasilkan kuat lentur tertinggi adalah pola anyaman dua sumbu, yaitu sebesar $4.54 \mathrm{MPa}$ untuk TRC serat rami tanpa dilapisi UPR dan 7.84 MPa untuk serat rami yang terlapisi UPR. Semakin banyak sumbu anyaman akan menurunkan kuat lentur TRC. Kekakuan dan daktilitas TRC serat rami pada setiap pola anyaman memiliki nilai yang sangat bervariasi. TRC serat rami pada setiap pola anyaman memiliki perilaku retak yang relatif sama namun nilai beban dan lendutan ultimit yang dicapai berbeda.

\section{DAFTAR PUSTAKA}

Alamsyah FT, Stefanus AK, Santosa B. 2017. Pengembangan Textile Reinforced Concrete (TRC) slab menggunakan serat cantula dengan berbagai anyaman. $E$ Jurnal Matriks Teknik Sipil. 5(4): 1362-1369.

[ASTM] American Standard Testing and Material. 2003. Standard Test Method for Flexural Properties of Thin-Section Glass-FiberReinforced Concrete (Using Simple Beam with Third-Point Loading). ASTM C947-03. Pennsylvania (US): ASTM International.

Brameshuber W. 2006. Textile Reinforced Concrete. Bagneux (FR): RILEM Publications.

Colombo I, Magri A, Zani G. 2013. Erratum to: Textile Reinforced Concrete: $\quad$ experimental investigation on design parameters. Mater Struct. 46: 195 $-1971$.

[EFNARC] European Federation of National Associations Representing for Concrete. 2005. The European Guidelines for Self Compacting Concrete. EFNARC 2005.

Fajri RI, Tarkono, Sugiyanto. 2013. Studi sifat mekanik komposit serat Sansevieria cylindrica dengan variasi fraksi volume bermatrik polyester. Jurnal FEMA. 1(2): 8593.

Gayathri CN, Singh RB, Dhanalakshmi G. 2018. Mechanical behavior of textile reinforced concrete. IRJET. 5(5): 2227-2231.

Kadir A. Aminur. Marzan. 2014. Pengaruh pola anyaman terhadap kekuatan tarik dan bending komposit berpenguat bambu. Jurnal Ilmiah Teknik Mesin. 6(1): 9-18.

Lorenz E, Schütze E, Schladitz F, Curbach M. 2013. Textilbetongrundlegende untersuchungen im überblick. Beton und Stahlbetonbau. 108 (10): 711-722.

Mechtcherine V. 2013. Novel cementbased composites for the strengthening and repair of concrete structures. Construction Building Material. 41:365-373.

Mueller DH, Krobjilowski A. 2003. New Discovery in the Sifates of Composites Reinforced with Natural Fibers. Journal of Industrial Textile. 33(2):111-130.

Naidu AL, Jagadeesh V, Bahubalendruni MVAR. 2017. A review on chemical and physical properties of natural fiber reinforced composites. International Journal of Advanced Research in Engineering and Technology. 8(1): 56-68. 
Nurlina S, Suseno H, Hidayat MT, Pratama IMY. 2016. Perbandingan daktilitas balok beton bertulang dengan menggunakan perkuatan CFRP dan GFRP. Rekayasa Sipil. 10(1): 62-69.

Portal NW. 2013. Sustainability and flexural behavior of textile reinforced concrete [Tesis]. Gothenburg (SE): Chalmer University of Technology.

Purwanto E, Kristiawan SA, Prabaswara D. 2020. Pengaruh variasi anyaman lateral seratcantula (Agave cantula roxb) pada Textile Reinforced Concrete (TRC) terhadap kuat tekan beton. EJurnal Matriks Teknik Sipil. 5(4): 15-21.

Rahardjo T. 2008. Study eksperimental pemanfaatan serat rami (Boehmeria nivea) sebagai bahan penguat komposit polimer matrik polisterin. Jurnal Flywheel. 1(1): 27-33.

Ujianto M. 2006. Lendutan dan kekakuan beton bertulang dengan lubang segi empat di badan. Jurnal Eco Rekayasa. 2(2): 52-57.

Schuh T, Gayer U. 1997. Lignocellulosic-Plastics Composites. Botucatu (BS): Unesp Publishers.

Yin $\mathrm{S}, \mathrm{Xu} \mathrm{S}, \mathrm{Li} \mathrm{H}$. 2013. Improved mechanical properties of textile reinforce concrete thin plate. Journal of Wuhan University of Technology. 28: 92-98.

Wibowo NA. 2019. Designing of flow mortar design mix for Self Compacting Concrete (SCC) with FWC $=0.4$. Journal of the civil engineering forum. 5(1): 3946. 
JSIL | Budiman dan Erizal : Pengaruh Pola Anyaman terhadap Perilaku Lentur Textile Reinfarced Cancrete (TRC) 